manufacture was completed by the addition of a small quantity of sugar.

The amateurs of fresh "Epping butter" were supplied with this daint $y$, which yielded my ingenious landlord a profit of at least one hundred per cent., besides establishing his shop as being supplied with Epping butter from one of the first-rate dairies. I am, Sir, your obedient servant,

York-road, Lambeth, June, 1853. A StUdent.

\section{POOR-LAW MEDICAL OFFICERS AND BOARDS OF GUARDIANS.}

To the Editor of The LANCET.

Sir,-Your leading article of last week conveys a wrong impression as to some of the facts relating to the Reigate Union and myself.

The figures quoted by you represent the extent of my district, and not the population; and as to the other circumstances, perhaps the enclosed copy of a letter to the chairman of the Board will best explain them.

I am, Sir, your obedient servant,

London, June, 1853 . J. B. BUDGETT.

To the Chairman of the Board of Guardians of the Reigate Union.

SIR,-I have already informed your clerk of my resignation of the appointment of medical officer of a district of your Union, but deem it my duty to state to the Board some of the reasons which have induced me to do so.

It will be remembered that when I was appointed it was stated that the districts were to be revised and the salaries equitably apportioned; but by my letter of Nov. 16th, 1852, it will be seen that at that time (eight months afterwards) no alteration was made; and that by the half-yearly medical returns it appeared that $I$ had attended 267 cases of illness at an average charge of $1 s .7 \frac{1}{1} d$. each, whilst the cases of the other medical officers in my district averaged $3 s .3 d$. and 3s. 9d. each.

I also asked for returns of area and population of my district, which I never could obtain. To all applications on these points I could get no definite reply. I therefore had made up my mind to resign, on the ground of inadequate remuneration and the non-fulfilment of the promise to re-arrange the district. However, in the course of my duties I came in contact with what I considered abuses, and failed not to denounce them. Amongst others, I point to the fact that I have relieved the Union of a pauper who had received pay for ten or eleven years, and who has the last eight or nine months done without it. In another case, where I supposed I might effect a cure, (Peter Wood's daughter, ) after five years' pay, and the probability of ten or fifteen or more years in prospective, (see accompanying certificate), - I say that in this case my professional opinion was overridden in a most unjust, and, I submit, most unbusiness manner, at the instance of an ex officio guardian. Because I expostulated with him he became a personal enemy, and was the mover of all the resolutions at the Board relative to my suspension; which being now removed by the order of the Poor-law Board, I hold myself exonerated from all blame in the matter; and feeling that it would be impossible for me to discharge my duties in a manner to satisfy a person who has sent his servants to canvas amongst the paupers for complaints against me, and who has called ont of church and had private conferences with the paupers who alleged that I had neglected them,-I say that when an ex-officio guardian will do this, (and I am prepared with names, times, dates, and circumstances,) the character of no medical officer, however diligent or ardent in the endeavour to do his duty, can be safe for a single day.

Finally, I had intended to continue the duties of $\mathrm{my}$ office till I could have explained these facts to the Board, but $I$ have for the last three or four weeks been suffering severely from bronchitis, so that in fact I am physically unable at this moment to continue the duties, and am quite unable to procure a substitute for the inadequate remuneration. I have no alternative therefore but at once to resign the appointment, and subscribe myself, Sir, your obedient servant, Horley, May 9, 1853. J. B. BUDGETT.

\section{[COPY.]}

I have this day seen the above case, with Mr. Smith, of Crawley, and it is my opinion that by a judicious combination of diet, nursing, and professional attendance, considerable relief may be afforded to the patient. I think it highly improper to carry the patient up and down stairs daily, and I attribute much of the curvature of the spine to that proceeding. It is next to impossible to ensure proper diet and attendance at her present residence, therefore $I$ have suggested the propriety of her admission to some institution where those requisites can be supplied; and, looking at the fact of her having remained five years in her present condition, with apparently little increase, if any, of her complaint, I have hopes that relief might be afforded, if not a cure effected. At the same time I cannot consent to abandon as hopeless the case of a pauper, which, as a private patient, no sane medical man would think of doing.

Nov. 26,1852 .

J. B. Budgett, Med. Officer.

I agree generally in the above opinion, particularly in that portion which indulges a hope of benefit from judicious feeding, quietude, and medicine of a tonic and sustaining character. The patient has no disease of a vital organ that I recognise. So far as to facts and objects to be obtained, it is obvious the above conditions cannot be attained at home; of the sacrifice, $\mathrm{I}$ apprehend, the parents must judge.

Crawley, Nov. 27, 1852.

Thos. Sмiтн, Surgeon.

** In the second leading article on the Horley Union, June 11, the figures were correctly given.-SuB. ED. L.

\section{THE COUNCIL OF THE COLLEGE OF SURGEONS.} To the Eiditor of THE LANCET.

Sir,-The well-merited strictures of "A Fellow by Examination," on the late conduct of the Council of the College of Surgeons, must meet the hearty approval, not only of all the fellows of his grade, but of those gentlemen on whom the fellowship was conferred as an acknowledgment, honourable to them, of their standing in the profession; to them a boon was granted, which, as an honour, the Council have now rendered valueless, while to the fellows by examination the Council have forfeited their solemn assurance that other than by examination the fellowship should not be attainable after August, 1844. It is much to be desired that a correct knowledge conld be obtained of those members of the Conncil who have, by advocating the sale of the fellowship, rendered them. selves eminently obnoxious, lest in the indiscriminate use of the black ball (as proposed) to "all who form part of the assembly" the upright and honest should suffer equally with the venal and unworthy. Some are known, and may anticipate their reward; but it would be well for those who have endeavoured to save the fellowship from abasement, and the Council from dishonour, to ward from themselves the obloquy they now innocently share, and to avoid the punishment the "Fellow by Examination" proposes, in the infliction of which I with many honorary fellows will most cordially assist him. I am, yours, \&c.,

June, 1853. A Frllow of the College of Suggeors.

\section{ST. THOMAS'S HOSPITAL.} To the Elitor of THE LANCET.

Sir,--Your correspondent is in error in stating that $I$ have been appointed Professor of Clinical Surgery. In common with my colleagues on the surgical staff, I give, and shall continue to give, occasional clinical lectures, generally once a week, more frequently, perhaps, than my colleagues, merely because I give no other lectures in the medical school. I must also add, in justice to all persons connected with the administration or with the staff of the hospital, that I have no reason whatever to believe that any opposition is now, or ever has been, contemplated to my election as full surgeon. Yours obediently,
st. Helen's place, Bishopsgate-st.,
Juue, 1853.

\section{PROPOSED COLLEGE OF MEDICAL ASSISTANTS.} To the Editor of THE LanceT.

SIr,--In fulfilment of the promise contained in my letter which you were good enough to publish in THE LANCET of June 4, I beg to offer a word or two more of comment on the proposed College for Medical Assistants, as suggested by your Wigan correspondent, and on other matters that personally affect assistants as a body.

I must own that when I first read your correspondent's letter, I was a little awe-struck at the dignity of the title he proposed to give to the new institution, The wherewitbal to originate and keep alive an establishment with so imposing a name, was the 